\title{
THE FORMATION OF LAND CONSERVATION PRINCIPLES AS THE FRAMEWORK FOR THE IMPLEMENTATION OF THE CONCEPT OF SUSTAINABLE DEVELOPMENT OF SOCIETY
}

\author{
MOLDIR ABAIKYZY ${ }^{1}$, LAZZAT K. YERKINBAYEVA ${ }^{2}$, KULYASH N. AIDARKHANOVA ${ }^{2}$, \\ GULNAR T. AIGARINOVA ${ }^{2}$, NURZHAN S. BAIMBETOV ${ }^{3}$
}

${ }^{I}$ Department of Civil Law Disciplines, Zhetysu State University named after I. Zhansugurov, 050060, 187a I. Zhansugurov Str., Taldykorgan, Republic of Kazakhstan. E-mail: moldir.a.r@kpi.com.de.

${ }^{2}$ Department of Customs, Financial and Environmental Law, Al-Farabi Kazakh National University, 050040, 71 al-Farabi Ave., Almaty, Republic of Kazakhstan. E-mail: lazzat@uoel.uk.,aidarkhanova@unesp.co.uk.,gul-aigar@ubogazici.in.

${ }^{3}$ Department of Law, Kainar Academy, 050040, 7 a Satpaev Str., Almaty, Republic of Kazakhstan.E-mail: nurzhan@kpi.com.de.

*Corresponding author e-mail: moldir.a.r@kpi.com.de

Received: $7^{\text {th }}$ August 2020, Accepted: $9^{\text {th }}$ September 2020

\begin{abstract}
The interest in the experience of legislative solutions to problems connected with the design and development of legal institutions in environmental protection in foreign countries, at first glance, is not directly related to the study of the laws of functioning and development of this legal institution. The relevance of the study is determined by the fact that such an interest appears as rather justified and even logical, if one is to proceed, firstly, from general ideas about the development of land legislation in the context of globalisation, and secondly, if one is to consider the desire of countries to more widely implement global and European standards of environmental policies and rights and approaches to environmental protection in general. The purpose of this article is determined by the identification the main problems of land protection legislation in the field of and form on their basis the effective system of environmental regulation, combining administrative and legislative instruments with economic, regulatory and market mechanisms. Analysis of international legal acts is used as the leading research method. It was determined that the positive experience in foreign countries related to the legal regulation of relations in legal protection of the environment allows transferring the theoretical ideas about the legal structures existing in other countries to the practical plane, which, in turn, allow to optimally regulate the appropriate circle of public relations, taking into consideration the relevant historical traditions, the internal structure of national legislation, the features of the development of environmental legislation of the respective country. The concept of protecting land from pollution by hazardous substances and ways of improving and adapting legislation in the field of waste management were proposed. The practical significance of the study is determined by the need to integrate the land legislation industry into national environmental legislation.
\end{abstract}

Keywords: land resources, regulation, law, protection, sustainable development. 
Abaikyzy M., et. al.: The formation of land conservation principles as the framework for the implementation of the concept of sustainable development of society

\section{INTRODUCTION}

Environmental protection is a recognised priority of national environmental policy and the subject of increased attention of the international community and European states (Warren, 2015). It is worth noting that every year the general state of the environmental situation in the country worsens (Sviderskyi et al., 2019). This problem is of particular concern to the state (Borská, 2015). One of the priorities of modern national policy is to conduct a comparative legal study of the compliance of legislation with European and world legal standards, as well as a comprehensive comparative legal analysis of the regulation of relations in protecting human health and life, the environment, including land, flora, and fauna (Rodríguez-Rodríguez \& Martínez-Vega, 2018).

World experience shows that solutions to environmental, economic, and social problems need to be considered through the improvement of land relations (Dirman et al., 2018). Therefore, with the involvement of the scientific potential and practical use of European and world experience regarding the legal protection of land, it is possible to lay the foundations of land protection at the national level (Wulandari et al., 2020). Along with this, the European and world experience of harmonisation indicates that the vast majority of activities in this area are caused not by environmental needs, but by considerations of international trade and ensuring freedom of trade (Hua, 2014). Harmonisation of national policies and legislation in environmental protection, including land resources contaminated with hazardous substances, is always a compromise between two interest groups: economic and environmental, which are contradictory in nature. Their oppositional nature grows when environmental interests appear to be remote in the context of "trade - environment", and vice versa, interests are reconciled in the face of a close environmental threat (Cieraad et al., 2015). The purpose of this article is determined by the identification the main problems of land protection legislation in the field of and form on their basis the effective system of environmental regulation, combining administrative and legislative instruments with economic, regulatory and market mechanisms.

An increased interest in studying the specific features of the legal protection of land from pollution by hazardous substances is caused by the legislation of one of the leading countries of world politics - the United States of America. This interest in solving the problem of legal protection of land from pollution by hazardous substances in the United States is not accidental, because currently the United States has gained considerable legal experience in this area. Thus, in US law, a new legal community has recently emerged, which is referred to in the American legal literature as "land use control" or "land use law", in other words, legal regulation of the use and protection of land. It must be emphasised that in this case, the legal impact on the process of use and protection of land in this country is not a new phenomenon. To a certain extent, the state exercised regulatory influence on it both in the colonial period of its history and after the revolution. However, the specific feature of the present moment is that, due to objective conditions caused by life itself, the need arose for creating unprecedented production forces and the social development of society; only at present this legal regulation is acquiring new qualitative features, it is undergoing profound and significant changes that relate to the foundations of law itself.

World practice shows that the conservation and protection of land resources, especially high-productivity ones, are specially addressed (Pawlikowska et al., 2017). In many foreign countries, a strict policy is being pursued to preserve the potential of arable land while intensively using it (Aleknavitschus, 2002). At the same time, land plots of productive land are included in national registries, and this is a serious barrier to their withdrawal for non-agricultural needs (Hilaire et al., 2019). Therefore, starting from the 1990s, the EU 
countries started developing concepts of High Nature Value for agricultural and forestry land (The application of the High Nature..., 2020), high natural value of agricultural land (High Nature Value Farm Land) (Pointereau et al., 2007).

The main objective of these projects was to establish the geographical distribution of highly productive lands by their categories, map the latter, determine the areas of each category of valuable agricultural and forestry lands within administrative units and monitor them (Terra et al., 2014). As a result, management methods for these lands were formed, which were considered in national land use programmes. According to the above concepts in Greece, lands of high natural value are divided into three categories: High Nature Value of forests; High Nature Value of forest land used for grazing; High Nature Value of arable land and forage land. This approach allows to allocate 6.89 million hectares of land in the country that can be considered as especially valuable, of which 2.05 million hectares are highly productive fodder land located on forest lands, 2.42 million hectares are highly productive arable land and 2.42 million ha are high natural value forests. It must be emphasised that the allocation of such lands in Greece is provided at the national and regional level.

\section{LITERATURE REVIEW}

In modern conditions, the anthropogenic load on land resources is increasing, often crossing national borders, thereby affecting the interests of different states (Issii et al., 2020). Features of international legal protection of the environment from radioactive contamination are conditioned by the special nature of such pollution. Therefore, it is not the pollution that should be addressed, but the contamination of the environment with radioactive substances, including waste, since by the nature of their physical properties they are stored in nature for a long time (Sizov, 2010). It is the long-term preservation of radioactive elements and their impact on all living organisms that determine the environmental protection features from radiation pollution (Sichko, 2010). Protection in this case means, first of all, the prevention of such infection that may arise as a result of the use of nuclear weapons, due to technical shortcomings of nuclear energy, and if necessary, the disposal of nuclear waste (Gordos, 1989).

The next article we examined is devoted to the study of the state of pastures in central Oregon. Climate change and land use change will likely have a serious impact on ecosystems sagebrush steppes of the western United States during the next century (Creutzburg et al., 2014). The approach presented in this paper allows researchers and managers to examine long-term trends and uncertainty in rangeland vegetation condition and test the effectiveness of alternative management actions under projected climate change. Decision-making and regulatory policies for the management of contaminated land are usually guided by risk assessments (Reinikainen \& Sorvari, 2016). The following article provides an introduction to the Finnish risk-based regulatory framework, outlining the issues related to policy and practice. This paper shows how some of the challenges associated with risk-based decision making have been addressed in the Finnish regulatory framework for contaminated land.

In the matter of nature conservation, the contractual form of cooperation between individual states is becoming more important (Josl, 1980). Suffice it to say that about 2 thousand international congresses, assemblies, conferences, symposiums were held on environmental issues, at which various aspects of the environmental protection of humanity were considered (Tomakov et al., 2019). Therefore, the international cooperation, which begun in the middle of the last century in this area, significantly contributed to rapprochement based on the developed international legal provisions of different countries and their domestic land legislation designed to protect the environment (Johnson \& Fitzhugh, 
Abaikyzy M., et. al.: The formation of land conservation principles as the framework for the implementation of the concept of sustainable development of society

1976). In this regard, there is currently an urgent need to harmonize the content of national legislation with international law, clarify the legal affiliation of natural resources, and ensure compliance with the legal regime for their use and protection (Issii et al., 2020). In international legal acts, the harm caused by environmental pollution by a dangerous substance or hazardous activity relates to civil liability. These provisions are specified in the Geneva Convention on Civil Liability for Damage Caused by the Transport of Dangerous Goods by Road, Rail, and Inland Water Transport (1989) (Convention on Civil Liability..., 1989a). The authors emphasise that the Convention has established that the carrier is liable for damage caused by any dangerous goods during carriage since the incident.

Nowadays, the degree of international legal support for the protection and rational use of specific natural resources and objects is different. Therefore, it can be stated that there are no clear and direct international legal mechanisms for regulating relations with respect to the legal regime of land protection, but conventions that are aimed at combating and counteracting various types of pollution can be considered as international legal acts that indirectly determine land protection. In the authors' opinion, this group should include the Aarhus Convention on access to information, public participation in decision-making and access to justice in environmental matters dated 25.06.1998 (Convention on Access to Information ..., 1998), Convention on Environmental Impact Assessment in a Transboundary Context of 25.02.1991 (Convention on Environmental Impact..., 1991), Declaration on Environmental Pollution adopted on 1.10.1976 in São Paulo (Declaration of the United Nations..., 1972), Stockholm Convention on Plastic Pollutants of May 22, 2001 (Stockholm Convention on Persistent..., 2001), Basel Convention on the Control of Transboundary Movements of Hazardous Wastes and their Disposal of 05.05.1992 (Basel Convention on the Control..., 1992), Convention on Transboundary Effects of Industrial Accidents of March 17, 1992 (Convention on the Transboundary Effects..., 1992), the Convention on Civil Liability for Damage Caused during Transhipment of Dangerous Goods by Road, Rail, and Inland Water Transport of 10.10.1989 (Convention on Civil Liability..., 1989b), Rotterdam Convention on the Prior Informed Consent Procedure for Certain Hazardous Chemicals and Pesticides in International Trade of 10.09.1998 (Rotterdam Convention on the Prior..., 1998).

Among the main international documents on environmental protection are also the World Charter of Nature, adopted by the 37th session of the UN General Assembly, which made all states responsible for the conservation of the planet and its environment (World Charter for Nature, 1982), and the Declaration on environment and development, adopted by the 1992 UN Conference in Rio de Janeiro (Rio Declaration on Environment..., 1992). The Conference (Articles 1, 3, 7 of the Declaration) established that to achieve sustainable development, environmental protection should form an integral part of the development process and cannot be considered in isolation from it. To avoid serious or irreparable damage to ecosystems, Principle 6 of the Declaration requires that toxic and other substances and heat emissions be released into the environment in quantities and concentrations that exceed the ability of the environment to render them harmless.

\section{MATERIALS AND METHODS}

In the process of researching the problems of this scientific work, general scientific and theoretical research methods were used. The main method of research is the method of analysis of scientific and legal literature on the stated research issues. The author analyzed and studied the publications of scientists who have studied the principles of land protection. 
Regulatory documents of the EU and the United States on nature protection and conservation were also analyzed. In the context of this paper, the author reviewed the basic terms and definitions. The authors studied the basic terms and international legislation related to issues of environmental protection and protection of land by using different methods. Methods of analysis and synthesis are used to determine the positive and negative aspects of the legislative systems of the United States and European countries in land protection. This paper analyzes the legal norms that are the basis for the regulation of environmental and land protection issues.

The generally accepted methods of scientific knowledge were used to study the basic issues related to land protection. The following methods were used: dialectical method, historical method, method of formal logic, method of synthesis and systematic analysis of data. Also, formal-legal and comparative-legal methods were used. Using a dialectical method of research, the article objectively and specifically considered the state regulation of land protection in the US and the EU. The dialectical method is based on such methods of information processing as: data synthesis and analysis, abstraction, as well as the principle of convergence from abstract concepts to specific ones. The long-term experience of European countries and the United States is considered using the dialectical method. The historical method was used to study historical data and information. The principles and legal norms used in the EU and the USA for the regulation of nature and land protection are studied. The initiation of a legislative framework on these issues in these countries was considered.

Formal logic is the science of laws and forms of theoretical knowledge at the level of abstract thinking. The method of formal logic is used for a more specific study of the research topic. Synthesis is also one of the methods of scientific knowledge, it involves an imaginary or material combination of parameters of one object, properties and features. A systematic method, or systematic data analysis, has been used to study the legal framework for land protection. Using a systematic method, we studied the concepts of protection and conservation of nature and land, as well as studied the legal framework for the legal regulation of environmental protection. System analysis is one of the basic methods of knowledge of state and legal phenomena, laws and regulations.

Formal-legal method, became the basis for research and analysis of known legal facts and regulations on environmental protection and land protection in the European Union and the United States. According to this method, we have consistently and logically studied the laws and regulations of the EU and the United States. The last method used in the research process is a comparative legal method. This method was used to study and compare legal documents and regulations in the EU and the US, it helped to compare and draw conclusions about different methods of regulating the issues under study. This method also helped to systematize information on differences in the legislation of different European countries and the United States.

\section{RESULTS AND DISCUSSION}

The experience of the USA is very interesting from the standpoint of the state's respect for the protection of land, including from pollution by hazardous substances. Thus, the US and the EU are representatives of countries belonging to different legal families. Historically, each country has its own legal customs, sources of law, jurisdictional bodies, each country has formed its own legal mentality and legal culture. Legal diversity allows to refer to their originality, to the fact that each country has its own legal system. However, the current global tendency lies in the rapprochement and convergence of legal families. The US environmental process is influenced by culture, traditions and, as a consequence, legislation. The concept of 
Abaikyzy M., et. al.: The formation of land conservation principles as the framework for the implementation of the concept of sustainable development of society

environmental protection is determined at the legislative level and within the framework of the judicial system, implemented by authorities at various levels of government. Therefore, the protection of lands and soils, including from pollution by hazardous substances, in the USA is the environmental economic and political task of society, carried out at the federal, regional, and local levels, and protection means the preservation and restoration, if possible, of human and natural resources.

An important role in ensuring the protection and rational use of natural resources in the United States is played by other administrative bodies: the Department of the Interior, the Department of Health and Human Service, the Department of Justice, and others administrative departments (transport, trade, energy, Nuclear Regulatory Commission, Federal Aviation Administration, Army Corps of Engineers). The system of the Department of the Interior includes the Bureau of Land Management, the Natural Resources Management Service, the National Park Service, the Fish and Wildlife Protection Service, the US Geological Survey, and the Bureau of Reclamation. The Department's activities are related to the implementation of federal measures to involve natural resources in economic turnover.

Despite the significant role of US federal agencies in environmental control, the main responsibility in this area lies with the state and local governments. At present, there are special departments for environmental protection in all states: ministries, agencies, administrations, commissions. In some states, several specialised bodies are being created: in the state of New York - the Bureau of Environmental Protection and the Department of the Environment, in Nevada - the Department of Natural Resources and the Commission on Environmental Protection. In environmental protection from pollution, including hazardous substances, these bodies are authorised to adopt sub-legislative acts, prepare action plans to monitor the implementation of federal environmental quality standards, sometimes developing such standards more stringently for their staff.

The main law of conservation and restoration of natural resources in the US agricultural sector is the five-year federal agricultural law, which periodically defines, reviews, and approves the main legal mechanisms - agro-environmental programmes. The main environmental areas of such programmes are: conservation of land and other natural resources based on long-term conservation of environmentally vulnerable and degraded lands; restoration of the potential of land and other natural resources directly in production based on the introduction of environmentally-friendly technologies, practices and management methods. The voluntary nature of land protection in the United States is expressly evident in agro-environmental programmes, which are almost 100 percent built on the use of partnership mechanisms, according to which farmers and land owners are economically encouraged by government agencies for the voluntary conservation and restoration of land resources.

Thus, US law does not contain any restrictions for concluding land transactions regarding the preservation of the intended purpose of agricultural land, there are no requirements for the buyers of such lands to have agricultural knowledge or experience. The problems of agricultural land use are solved in this country through zoning, as well as through taxation and the mechanism of state subsidisation of farmers. Additional agroecological programmes are defined in the Regulation "On Protection" of the 2002 Federal Law on Agricultural Safety and Agricultural Investments. Among these main programmes:

1) The programme for the conservation of farm land and pastures, including fertile, valuable, and other productive soils, historical, and archaeological lands;

2) The programme for the provision of standardised technical aid to farmers, landowners on the implementation of agroecological projects on private agricultural lands. 
It is worth emphasising that in US law, land is defined as the unity of physical attributes and related subjective rights and obligations. Obviously, this approach to the formation of the legal attributes of a land plot is more productive, since it allows it to be delimited from the rest of the earth's surface and view it through the lens of legal obligations of subjects of land relations, and not only through the system of their rights to land plots. Therefore, the United States is one of the leading countries in the agricultural sector, the legal provisions of which reflect the balance between the use of land as the main natural resource and means of production; upon imposing enhanced legal protection on land in the United States, as elsewhere in the world, there is growing interest in recycling. This practice has begun to acquire considerable scope over the past three decades.

In Germany, the following types of lands of high natural value include: high-productivity pastures, fallows, highly productive arable land, orchards, valuable vineyards, habitat types according to the directive of residence within the agricultural landscape (legal protection of biotopes within the agricultural landscape); landscape features (for example, land of ditches, fences, soil parts of roads, reservoirs of small streams, dry stone walls). Furthermore, in the United States there are numerous examples of highlighting the classification of especially valuable lands as the basis for maintaining their uniqueness or high productivity. However, in the United States the term "especially valuable lands" is not used, although the allocation of the most important and unique agricultural lands is provided, which to a certain extent corresponds to the concept of "especially valuable lands".

Thus, the Natural Resources Protection Service uses three systems for assessing the quality of agricultural land, one of the components of which is the classification of the most important lands in rural production. For this purpose, a generalised classification of them has been developed, containing the identification of especially valuable lands as part of the national resources of the state. The mentioned classification provides for two main categories of land: the best agricultural land and unique agricultural land. It is also necessary to pay attention to the fact that in the USA special attention is paid to the protection of unique agricultural lands and the possible decrease in the production potential of agricultural production. For this purpose, they are mapped (on a base scale of 1:50 000 and 1:100 000) and inventory, and information on the geographical distribution, size, area, and other features to be made public is used by the relevant departments at the national and local levels of government.

Another interesting fact is that in 1982 the National Association of Waste Mineral Oils (A.N.C.O.M.E.) was created in Italy as an association of enterprises that collect various wastes, including waste batteries and vegetable oils. The collected waste oils are analysed and, depending on the results, sent for recycling, physical and chemical treatment, or burning. The authors note that the result of waste recycling can be not only the production of a certain type of product, but also the provision of certain types of services. Currently, there are six plants for the recovery of waste oils in Italy, with a total capacity of 239 thousand tons per year, $18 \%$ of the collected oils go to combustion as fuel. A similar situation exists in other developed countries of Europe and the world - there, the systems for collecting and processing used oils are functioning successfully to a certain extent.

Furthermore, along with the production of products, recycling includes the production of electricity, gas, fuel, and thermal energy as a product with high capacity. Thus, according to statistical data, on average only $25 \%$ of the total volume of oil consumption is collected in the world, of which only $15 \%$ is regenerated, which roughly corresponds to $3 \%$ of the total volume of consumption. This leads to the fact that from $30 \%$ to $50 \%$ of the waste oils of private vehicles enter the environment and sewage. As is known, the problems that arise in rational use of land resources are inherent in all industrialised countries. The leading 
Abaikyzy M., et. al.: The formation of land conservation principles as the framework for the implementation of the concept of sustainable development of society

countries where the greatest burden on land resources is produced include China, the USA, Russia, Germany, Brazil, France, and Great Britain. The problem of protecting land resources is a global problem, and it must be solved by joint efforts by unifying and integrating legislation in protection of land resources from socially dangerous encroachments.

Since 1943, the UK adopted the world's most advanced land use planning and protection system at that time, which is especially important for highly urbanised countries with a high population density. The authors note that upon organising the rational use and protection of land in the UK, methods of territorial land management related to changing the boundaries, plan, and location of land were widely used. Therefore, the UK has is a strict system of control over the use of land and other real estate. This is conditioned by the fact that a change in the purpose of the land may entail a significant increase or decrease in its value. According to British experts, the information basis for land management in the UK differs from other European countries. They believe that if in Europe, planning, land management, and land valuation are based on the land cadastre, then the UK has no such formal land cadastre.

However, control over the use of land also has its distribution. According to the Law on Pollution Control of 1974, local authorities are entrusted with the functions of preventive control of land pollution with hazardous waste. Local authorities can hold perpetrators accountable for illegal emissions and transportation of waste without special permission. Furthermore, UK agricultural laws give the Secretary of Agriculture or their appointee the right to periodically inspect all agricultural enterprises. Having discovered the improper use of land or farming, the minister can exercise control over the farm, and in some cases, terminate the lease; replace the tenant with another person, transferring the right to lease to them; attribute changes to the purpose of land on the farm. The UK has gained positive experience in contractual regulation of protection relations on agricultural land. Management agreements between the authority and owners or users of agricultural land constitute a means of extending legally binding control activities to the agricultural use of lands subject to special protection. Moreover, such agreements are not only negative, prohibitive, but may also impose positive and useful obligations on the owners and users of land in rural areas in the public interest.

The authors note that one of the main dangers in the UK is the storage or use of toxic, explosive, or flammable substances, which, in case of emergency can adversely affect the local population and nearby territories. Such emergencies are rare, but the potential risk or threat is demonstrated by the number of major potential disasters and, to a lesser extent, by cases in certain territories of this country. Thus, in the UK on 10.10.1957, an accident occurred at one of the weapons-grade plutonium test reactors, ranked by the International Atomic Energy Agency (IAEA) as tier VI on the international scale of events at a nuclear power plant (NPP). A fire occurred in the reactor core, as a result of which the release of radionuclides into the environment occurred, about 11 tons of uranium burned out.

After such a severe nuclear accident, the UK government started paying more attention to the safety of nuclear energy production, the country's social and political climate was hostile to the development of nuclear energy sector in general. Later, thanks to the state safeguards policy, through the adoption of several new regulations and the introduction of substantial changes in the current legislation, nuclear energy sector has relatively stabilised. Thus, the following regulation comprise the fundamental framework of the UK legislation in nuclear energy sector and the restoration of the territories affected by the accident: Laws "On Social Security" of 1935 with reformative amendments of 1994; "On Nuclear Energy (Under Different Conditions)" dated 1946 as amended on 1989; "On Radioactive Sources" dated 1965; "On Energy Conservation" dated 1978, as amended in 1981; "On Financing the 
Nuclear Industry," dated 1981; “On Nuclear Materials," dated 1983; The Main Law "On Atomic Energy" of 1954, as amended in 2004; Laws "On Ecology Protection" dated 1990; "On Clean Air" dated 1993; "On Radioactive Objects" dated 1993; "On Nuclear Explosions (Prohibition and Control)", dated 1998.

Almost all projects for the revival of economic viability of contaminated territories as a result of a radioactive accident were of an individual, local nature. They comprised the decontamination and dismantling of radioactively contaminated structures and restoration measures, requiring constant increased attention and support for such measures both from the state and economic entities. The first attempt to solve the problem of land pollution by hazardous substances was the recommendations of the UK government in the 1970s. They intended to ensure the technical implementation of best practices for the management of various types of contaminated territories, provided that such territories are defined. At that time, it was believed that contaminated land was a matter of resource planning. These issues were highlighted in critical reports by the Royal Commission on Environmental Pollution. In 1990, the House of Citizens elected an environmental committee. This made the UK Government scrutinise legislation and the act, which was adopted in 1990, made reservations that required the creation of registries of potentially contaminated zones. The creation of an environmental agency as a consultative and expert centre was also proposed, where the local parliament would play a key role in ensuring and planning the decision-making process.

In 1969, an underground nuclear reactor accident occurred in Switzerland, in which case radiation did not have a large negative impact on the environment, since the reactor was located in a cave and all radioactive emissions remained inside. The main task that the Swiss government sets itself in the direction of nuclear safety of economic activity is the disposal of spent nuclear fuel. Its first step in this direction was the identification of six regions for storage facilities in 2011. The following priority provisions were also identified as part of this development programme: paying great attention to scientific achievements, recruiting competent personnel for nuclear plants, disseminating information and knowledge about managing nuclear plants and disposing of spent nuclear fuel, conducting social dialogue, and determining public assessment.

In the same year as in Switzerland (1969), an accident occurred in France at the Saint-Laurent NPP, where a 500-mW reactor, which was put into operation, exploded. This resulted in overheating and core melting, about $50 \mathrm{~kg}$ of nuclear fuel leaked from the reactor. At present, the framework of French legislation in nuclear energy and safe management comprises several regulations: Law "On Nuclear Transparency and Safety", 2006; Council Directive 2009/71/Euratom of June 25, 2009, which establishes the safe handling of nuclear equipment by the public; Commission Decree of July 17, 2007, which defines horizontal relations in the highest management bodies for nuclear safety and nuclear waste management; Act of June 13, 2006 No. 2006-686, which covers transparency and security in the nuclear business; The programme for the management of radioactive materials and industrial waste dated 15.06.2006; Basic Safety Rules 2002-1 for assessing development and eliminating the likelihood of danger; Basic Safety Rules 2001-01 regarding the determination of seismic risk for the safety of external structures of nuclear installations; Basic safety rules concerning the determination of indicators of seismic movements that may damage the safety of major nuclear facilities; 2012 National Radioactive Material and Waste Management Plan. The French lawmakers, in all regulations, emphasise the importance of scientifically based security, the need for research work, transparency and democracy improvement in matters concerning procurement of information on such issues, monitoring the development of economic activity in nuclear energy, and in territories of post-radiation pollution, improvement of the economic development of such territories, determination of 
Abaikyzy M., et. al.: The formation of land conservation principles as the framework for the implementation of the concept of sustainable development of society

sources of income for financing such projects. Research plans for nuclear energy sector in France are approved by state legislative authorities until 2030.

The discovery and practical use of atomic and thermonuclear energy posed a problem for humanity to protect all living things on planet Earth from dangerous radiation. Of course, this problem is primarily solved within the framework of the struggle for peace, the distraction of thermonuclear war, and disarmament. A lot has been achieved in this matter, including in the legal aspect. There are a significant number of multilateral and bilateral international treaties, conventions, agreements, and other acts that, both in general and in relation to certain types of weapons, limit, constrain, prohibit the production, testing, and use of weapons of mass destruction, especially thermonuclear weapons. However, the threat of the use of nuclear and thermonuclear energy for military purposes has not been overcome.

At the same time, radiation safety measures in cases of the peaceful use of atomic energy also require great attention. The need for this has led to the development of international cooperation and the corresponding legal regulation of a complex set of interstate relations in this area. To prevent potential dangers arising from the use of nuclear material, interested states, under the auspices of the IAEA, have developed the Convention on the Physical Protection of Nuclear Materials and Nuclear Installations, which was opened for signature on March 3, 1980 in Vienna. The Soviet Union, Austria, Greece, the USA and several other countries were among the first to sign the convention. The Convention provides that each State Party shall, within the framework of its national law and in accordance with international law, take appropriate measures to ensure that, in the course of international transport, nuclear material located on its territory or on board a ship or aircraft that is subject to its jurisdiction defended itself. Earlier, the Vienna Convention on Civil Liability for Nuclear Damage of May 21, 1963, and the Brussels Convention on Civil Liability in Maritime Transport of Nuclear Materials of December 17, 1971 were adopted. According to the Convention of May 21, 1963, the operator of a nuclear facility shall be liable for nuclear damage, if there is evidence that such a loss is caused by an incident at the facility or is related to nuclear material obtained with it or to what is used in it.

In this regard, the provisions of the EU Convention on Civil Liability for Damage Caused by Activities Dangerous to the Environment, which was signed on June 21, 1993 in the city of Lugano, are conceptually determining. The purpose of this Convention is to guarantee appropriate compensation for harm caused by the effects of hazardous activities on the environment. As is known, a hazardous activity is defined by the convention, as any activity, including that carried out by authorities, if it is associated with the production, use, storage, and other handling or emission of one or more hazardous substances, or any other operations with these substances; production, cultivation, storage, use, destruction, disposal, releases or any other handling operations under the influence of which organisms change genetically, genetic changes are observed and conditions under which such changes are detected, or microorganisms emerge as a result of the properties of these actions and significant conditions arise that pose threat to humans, the environment, and property as a result of their pathogenic or toxicological effects. To compensate for the damage, it is proposed to introduce the latest technologies for cleaning the land and other natural components of the plot to achieve such a quality of the soil that the land plot is suitable for use at present and in the future.

Along with the study of international agreements and conventions that contain direct provisions regarding territories exposed to radioactive contamination, an important condition for the formation of an appropriate institutional and legal framework for soil protection is the availability of reliable information on the state of the soil cover. Thus, the creation of databases on soil cover and its condition in individual countries, and then in regions, districts, 
and the smallest administrative units, which is currently taking place in Germany, Hungary, the Czech Republic, Slovakia, Romania, the Netherlands and other countries, allows not only more to objectively plan land conservation measures with the involvement of local resources, but also to carry out an equally important work - to attract broad segments of the population and direct land users and landowners to land conservation activities.

The most comprehensive soil monitoring programmes are implemented in Austria, Germany, and Sweden. It is important to emphasise that in these countries monitoring is carried out based on ministerial instructions, but there are no state laws on soil monitoring. However, in Spain, where monitoring is much less developed, there is a model law on soil monitoring. The development of the soil monitoring network in Europe was significantly influenced by various EU directives on permissible concentrations of heavy metals, control of enterprise emissions, the use of effluents and industrial waste on agricultural land. Similar rights and obligations of land users to preserve and improve soil fertility are legislatively determined in other European countries. Thus, in Hungary, the Law on the Protection of Agricultural Land dated 02.24.1961 obliges agricultural enterprises to take all possible measures to maintain and improve soil fertility, as well as to prevent their destruction. This Law also establishes the legal liability of land users, regardless of the form and legal title of land use, for the destruction or reduction of soil fertility.

The legal protection of land in Hungary extends to the protection of soils, rocks, and entrails of the earth with minerals, but the protection of soils is given particular importance, and the system of protection of rocks and minerals has not yet been developed. Thus, the Law of Hungary on Nature Protection and the Land Law of 1987, paragraph 59(3), define land protection as a general duty, which requires landowners and land users to prohibit land pollution from industrial waste, emissions, and other pollutants. Production waste and chemical materials can be disposed of in the ground or accumulated in the soil only in accordance with the requirements specified in legal regulations or departmental regulations, however, apart from general regulations, specific legal standards for the protection of soil quality have not yet been developed. It is necessary to distinguish between land pollution by waste and emissions from industry, transport, utilities, on the one hand, and land pollution in the process of agricultural production, on the other. At present, it is determined that in Hungary several legal provisions have been developed to prevent soil pollution with agrochemicals, namely, rules that allow to use those products that successfully influence the increase of soil fertility. Therefore, by following these rules, it is possible to at least reduce the risk of mineral fertilisers as a threat to soil quality.

In the Czech Republic, the obligation of subjects of agricultural land use rights to maintain and improve soil fertility is established by a set of special laws. Thus, the Law "On the Development of Crop Production" of 1964 imposed an obligation on agricultural enterprises to take care of the correct and scientifically sound management of agricultural lands and to systematically increase their level of productivity through the planned implementation of measures that increase soil fertility. The Law "On the Protection of the Agricultural Fund" of 1966, as well as the decree issued in the same year on the procedure for applying this law, enshrined a wide scope of responsibilities for all users of agricultural land, including personal peasant farms and non-agricultural land users who use agricultural land. Thus, it is known that the Law "On the Protection of the Agricultural Fund" of 1966, by establishing the obligation of land users to maintain and improve soil fertility, proceeds from the position that all agricultural land plots should be cultivated and generally used without deterioration of soil fertility. Therefore, land users or landowners may be required by district committees to take, at their own expense, a number of measures to improve soil fertility and preserve the 
Abaikyzy M., et. al.: The formation of land conservation principles as the framework for the implementation of the concept of sustainable development of society

agricultural land fund, such as establishing proper crop rotation, cultivating land, draining, or irrigating land.

Thus, according to estimates of the International Monetary Fund, in these countries, the consumption of natural resources per unit of finished product is reduced annually by an average of $1.25 \%$, which causes a significant environmental effect, since under such conditions greening production is economically viable. This process is facilitated by the state financial and economic policy of stimulating the environmental activities of producers and enterprises with the help of an effective system of environmental regulation, combining administrative and legislative instruments with economic, regulatory and market mechanisms. The authors note that the Japanese Agricultural Land Act of 1952 contains significant restrictions on the alienation of agricultural land. The main purpose of this law is to ensure the principle that the owner is the user of the land. According to this law, all transactions in relation to agricultural land plots can be made in this country only after obtaining permission from the relevant authority, and transactions that may lead to the appearance of latifundia must be rejected. Therefore, in Japan, the agricultural land law is the main legal act the governs the control, use, and alienation of agricultural land, stipulates the refusal of permission to transfer land to foreigners if they are assessed as potentially leading to a large land tenure system.

In recent years, Japan has seen a decrease in the natural fertility of soils, as well as the irrational use of chemical fertilisers and pesticides. In this regard, there was a need to reduce the introduction of chemical fertilisers into the soil and increase soil fertility through the introduction of organic fertilisers. The Fundamental Law on Combating Environmental Pollution was adopted in 1967, and in 1993 the Fundamental Law on the Environment was adopted. It should be noted that for Japan it is typical for the environment to focus on, firstly, the development of health standards, supplemented by emission limits for certain industries and types of production, and secondly, on the development of regional (along with national) plans of socio-economic development, which is carried out with consideration of modern environmental imperatives. That is why the scale of production of hazardous industrial wastes, as well as causing real and potential damage to the environment if handled improperly, determined the adoption of the Law on Waste Management in Japan (1971), the violation of which carries other types of liability and criminal liability. But the introduction of technologies such as the Good soil management system, which includes the use of organic fertilisers and weed control, is considered to be the most efficient.

Many scientists have studied the legal regulation of environmental activities. We offer to consider some scientific works devoted to the subject of our research. Tomakov and other researchers in a joint study considered the problems of negative impact on land and soil during the construction of pipelines and discussed regulatory issues of regulation of these issues (Tomakov et al., 2019). The authors studied the basic regulatory and technical documentation in the field of environmental protection in the construction of main pipelines. The authors note that the analysis of environmental legislation has shown that measures to rehabilitate disturbed and contaminated land should be reflected in a separate document - the land reclamation project. Development and approval of this project are necessary for further construction of pipelines. The proposals formulated by the authors in the article can become a basis for the development of new theoretical models for improving environmental legislation. Also, this work may be useful for other research in the field of legal regulation of environmental protection in the construction of main pipelines.

Another work dealing with land pollution considers this issue in the context of Finnish legislation (Reinikainen et al., 2016). The authors note that most countries around the world are already pursuing policies and addressing land and environmental pollution. However, 
despite the accepted concepts and principles in the context of this issue, there are currently no clear international legal acts. In their paper, the authors propose to consider their own strategy and related policy measures for Finland. In the conclusions to this work, the authors note that the Finnish authorities have recognized the need to implement programs to combat land pollution, and finally adopted the above strategy. Also, the authors noted the need for constant cooperation with the government.

Considering the experience of many countries, such as the United States, the Czech Republic, Britain, France, Japan and many others, it can be noted that each country is trying to regulate land issues in its own way. The problems of nature and land conservation are important issues for the whole world. Therefore, to achieve the most productive results, countries must borrow positive experiences from each other. Cooperation and co-operation of countries can bring effective results in matters of land conservation and nature protection.

\section{CONCLUSIONS}

Thus, based on the above analysis, it can be concluded that the legal measures for the protection of land stipulated by the laws of the countries considered in the study can be divided into preventive measures aimed at aversion of negative consequences, assurance of rational use of land and restoration, related to the obligation of land users to compensate for the harm that has been lawfully and unlawfully caused to land resources in the process of their use. It is obvious that in the legislative activity of the state it is necessary to use integration processes more fruitfully and consider the positive experience of legal regulation of the land issue of such democratic states as the USA, Great Britain, and Germany, which have similar instruments of legal regulation. In opinion of the authors, the introduction of the Concept for the Protection of Lands from Pollution by Hazardous Substances, as well as the development and adoption of regional and national programmes in which a separate section should address issues of land protection from pollution by hazardous substances will yield positive results.

It would be appropriate to attract foreign companies that have the technology and experience in the collection and processing of municipal solid waste. For them, it is necessary to provide a system of economic preferences, consolidating them at the legislative level; to develop standards for fines for dumping garbage in undesignated areas, justifying the possible losses from damage to land resources. Thus, the adaptation of legislation in waste management constitutes a complex process, therefore, its clear planning is important. In our opinion, it is possible to single out such a sequence of adaptation of legislation in waste management: sector;

1) the definition of acts of acquis communautaire governing legal relations in this

2) the application of certain acts of world legislation on waste management in a local key;

3) a comprehensive comparative analysis of legal acts on wastes and their treatment;

4) development of recommendations on adaptation of legislation with acquis communautaire;

5) determination of the list of legislative work in this area;

6) preparation of draft laws and other regulations included in the list of legislative work in this area, and their adoption;

7) monitoring the implementation and control of legislative mechanisms. 
Abaikyzy M., et. al.: The formation of land conservation principles as the framework for the implementation of the concept of sustainable development of society

\section{REFERENCES}

Aleknavitschus, P. (2002). Land management and legal protection of ecologically sensitive areas (Lithuanian example). Zeitschrift Fur Kulturtechnik Und Landentwicklung, 43(5), 223-226.

Basel Convention on the Control of Transboundary Movements of Hazardous Wastes and their Disposal. (1992). Retrieved May 17, 2020 from http://www.basel.int/TheConvention/ Overview/History/Overview/tabid/3405/Default.aspx.

Borská, J. (2015). Legal aspect of the protection and use of land in the Czech Republic. In International multidisciplinary scientific GeoConference surveying geology and mining ecology management - SGEM, International Multidisciplinary Scientific Geoconference, Sofia, 711-716.

Cieraad, E., Walker, S., Price, R., \& Barringer, J. (2015). An updated assessment of indigenous cover remaining and legal protection in New Zealand's land environments. New Zealand Journal of Ecology, 39(2), 309-315.

Convention on Access to Information, Public Participation in Decision-Making and Access to Justice in Environmental Matters. (1998). Retrieved May 25, 2020 from https://www.unece.org/fileadmin/DAM/env/pp/documents/cep43e.pdf.

Convention on Civil Liability for Damage Caused during Carriage of Dangerous Goods by Road, Rail and Inland Navigation Vessels (1989a). Retrieved May 21, 2020 from https://digitallibrary.un.org/record/52697.

Convention on Civil Liability for Damage Caused during Carriage of Dangerous Goods by Road, Rail and Inland Navigation Vessels. (1989b). Retrieved May 21, 2020 from https://digitallibrary.un.org/record/52697? $1 n=r u$.

Convention on Environmental Impact Assessment in a Transboundary Context. Espoo, Finland, 25 February 1991. (1991). Retrieved May 21, 2020 from https://treaties.un.org/ doc/Treaties/1991/02/19910225\%2008-29\%20PM/Ch_XXVII_04p.pdf.

Convention on the Transboundary Effects of Industrial Accidents. Helsinki, 17 March 1992. (1992). Retrieved May 21, 2020 from https://treaties.un.org/doc/Treaties /1992/03/19920317\%2008-08\%20AM/Ch_XXVII_06p.pdf.

Creutzburg, M.K., Halofsky, J.E., Halofsky, J.S., \& Christopher, T.A. (2014). Climate change and land management in the rangelands of Central Oregon. Environmental Management, 55(1), 43-55.

Declaration of the United Nations Conference on the Human Environment. (1972). Retrieved May 25, 2020 from https://www.ipcc.ch/apps/njlite/srex/njlite_download.php?id=6471.

Dirman, E.N., Saleng, A., \& Sapiddin, A.S.A. (2018). Food agricultural land legal protection to improve food security in Indonesia. In IOP Conference Series: Earth and Environmental Science (art. No. 012047), Institute of Physics Publishing, Bristol. doi:10.1088/ 1755-1315/196/1/012047.

Gordos, S. (1989). Relation between environmental protection and preservation of arable land. Geodezia Es Kartografia, 41(2), 113-118.

Hilaire, T., Hanifah, M., \& Ardiyanto, S.Y. (2019). Legal protection for communal land to prevent land conflicts in both West Sumatra and Riau Provinces. Journal of Legal, Ethical and Regulatory Issues, 22(2), 1-4. 
Hua, Y. (2014). Legal regulation of land reclamation in China's coastal areas. Coastal Management, 42(1), 59-79. doi:10.1080/08920753.2013.865008.

Issii, T.M., Romero, A.C., Pereira-Silva, E.F.L., Attanasio, M.R., \& Hardt, E. (2020). The role of legal protection in forest conservation in an urban matrix. Land Use Policy, 91, art. No. 104366. doi:10.1016/j.landusepol.2019.104366.

Johnson, C.W., \& Fitzhugh III, T.C. (1976). Legal aspects of land use regulation of lake shorelands by state and local governments for the protection of lakes. Centre for Research in Water Resources, University of Texas, Austin, p. 84.

Josl, J. (1980). Legal protection of land used for agriculture in Czechoslovakia. Internationale Zeitschrift Der Landwirtschaft, 3, 245-247.

Pawlikowska, E., Popek, P., Bieda, A., Moteva, \& Stoeva, A. (2017). Analysis of the legal methods of agricultural land protection in Central Europe on the example of Poland and Bulgaria. Real Estate Management and Valuation, 25(2), 58-71. doi:10.1515/remav-2017-0013.

Pointereau, Ph., Paracchini, M.L., Terres, J.-M., Jiguet, F., Bas, Y., \& Biala K. (2007). Identification of High Nature Value farmland in France through statistical information and farm practice surveys. Office for Official Publications of the European Communities, Luxembourg, p. 76.

Reinikainen, J., \& Sorvari, J. (2016). Promoting justified risk-based decisions in contaminated land management. Science of The Total Environment, 563-564, 783-795. doi:10.1016/j.scitotenv.2015.12.074.

Reinikainen, J., Sorvari, J., \& Tikkanen, S. (2016). Finnish policy approach and measures for the promotion of sustainability in contaminated land management. Journal of Environmental Management, 184, 108-119. doi:10.1016/j.jenvman.2016.08.046.

Rio Declaration on Environment and Development. (1992). Retrieved May 20, 2020 from https://www.un.org/en/development/desa/population/migration/generalassembly/docs/globa lcompact/A_CONF.151_26_Vol.I_Declaration.pdf.

Rodríguez-Rodríguez, D., \& Martínez-Vega, J. (2018). Effect of legal protection and management of protected areas at preventing land development: a Spanish case study. Regional Environmental Change, 18(8), 2483-2494. doi:10.1007/s10113-018-1369-8.

Rotterdam Convention on the Prior Informed Consent Procedure for Certain Hazardous Chemicals and Pesticides in International Trade. Rotterdam, 10 September 1998. (1998). Retrieved May 17, 2020 from http://www.pic.int/Portals/5/download.aspx?d= UNEP-FAO-RC-CONVTEXT-2015.English.pdf.

Sichko, S.M. (2010). Normative-legal and economic support for usage and protection of recreational lands. Actual Problems of Economics, 2, 175-179.

Sizov, A.P. (2010). Legal regulation of soil and land protection in settlements of the Russian Federation. Eurasian Soil Science, 43(12), 1401-1409. doi:10.1134/S1064229310120112.

Stockholm Convention on Persistent Organic Pollutants. Stockholm, 22 May 2001. (2001). Retrieved May 25, 2020 from https://reaties.un.org/doc/Treaties/2001/05/ 20010522\%2012-55\%20PM/Ch_XXVII_15p.pdf.

Suci Wulandari, M.H., Sulistiyono, A., \& Karjoko, L. (2020). Legal politics of customary land regulation to provide equity in legal protection. International Journal of Advanced Science and Technology, 29(4), 1759-1766. 
Abaikyzy M., et. al.: The formation of land conservation principles as the framework for the implementation of the concept of sustainable development of society

Sviderskyi, O., Havrylenko, O., Kovalenko, K., \& Shlapko, T. (2019). Administrative and legal mechanism of land relations protection in Ukraine and Russia: comparative legal analysis. Asia Life Sciences, 2, 45-57.

Terra, T.N., dos Santos, R.F., \& Costa, D.C. (2014). Land use changes in protected areas and their future: the legal effectiveness of landscape protection. Land Use Policy, 38, 378-387. doi:10.1016/j.landusepol.2013.12.003.

The application of the High Nature Value Impact Indicator 2007-2013. (2020). Retrieved May 18, 2020 from http://ec.europa.eu/agriculture/rurdev/eval//hnv/guidance en.pdf.

Tomakov, M.V, Tomakova, I.A., Brezhnev, A.V, Pykhtin, A.I., \& Timoshenko, A.A. (2019). Disagreements between legal acts regulating environmental requirements for the use and protection of land in the construction of trunk pipelines. In International Multidisciplinary Scientific GeoConference Surveying Geology and Mining Ecology Management - SGEM, 189-196. doi:10.5593/sgem2019/5.1/S20.024.

Warren, L.M. (2015). Protection for aquatic habitats: Are land-based legal tools appropriate? Environmental Law and Management, 27(3-4), 154-160.

World Charter for Nature. (1982). Retrieved May 21, 2020 from https://digitallibrary.un.org/record/39295? $1 \mathrm{n}=\mathrm{ru}$ 